\title{
Research on the Mode of Cultivating Creative Talents in College English under the Background of "Internet +"
}

\author{
Saihanqiqige \\ Press Agency, Chifeng University \\ Chifeng 024000, China
}

Keywords: Internet+; University English; Innovation and entrepreneurship; Culture mode

\begin{abstract}
With the rapid development of world economy and technology, Internet technology has shortened the distance between people and brought great convenience to people's work, study and life. The rise of "Internet+" has brought an unprecedented transformation to Chinese education. The traditional teaching model based on textbooks, books, and notes has gradually been replaced by the Internet, cloud platforms, and flipped classrooms. How to rely on the "Internet + " advantage to enable every student to obtain high-quality teaching resources, give full play to the students' initiative, and cultivate students' innovative abilities is a problem that requires higher education. In this regard, this article aims to bring about the Internet + a tremendous change, proposed college English teaching to adapt to the trend of development of the times, play the "Internet + " advantage, technology innovation as a means of training, comprehensively improve the ability of college students to apply practice, to cultivate social needs, innovation Strong sense of the composite application talents.
\end{abstract}

\section{Introduction}

With the development of Internet technology and the arrival of the era of big data, the Internet has been integrated into all aspects of human life, and the era of Internet+ has come quietly. The Internet has been widely used in the medical field, industrial field, and commercial field. Its unique advantages such as sharing, rapidity, and convenience have brought tremendous innovations and changes to various industries. In this context, college English education must also adopt the "Internet+" education model to a certain extent, so as to keep up with the pace of development of the times, cultivate talents in the era of new technology, and keep up with the times of the times. As a beneficiary and creator of the Internet+ era, college students will be happy to use this emerging technology to learn English. If we combine English learning with the cultivation of undergraduates' innovative and entrepreneurial abilities, it will have a positive impact on the students' future innovation and entrepreneurship development. This article uses technology innovation as a means of education to build a knowledge-based, project-driven, and practical-focused education model that comprehensively enhances the ability of undergraduate students to apply practical skills, and cultivates talents that meet the needs of society, have a strong sense of innovation, and use complex talents.

\section{The Problems in College Traditional English Teaching}

College English is a course that transforms language content into specific behavioral abilities. However, current college English teaching is generally time-consuming and inefficient, and it cannot adapt to the requirements of China's economic development and international exchange for talents. The reasons for this are as follows:

Teacher Issues. For a long time, lecture-centered teaching has dominated, ignoring the application and innovation of knowledge. Despite repeatedly stressing that learners should be the center of English classes, college English class teaching is often based on students' preparation of new words and phrases. Teachers explain new words and phrases, then introduce the background of the text and explain the text sentence by sentence. In the teaching middle school, passive and blind "knowledge recipients" were created. Students passively participated in the teaching activities. They 
mainly listened to lectures and recorded notes, which led to lack of interest in learning and the lack of comprehensive English quality. As a result, students learn in class for ten years or longer. They learn "dummy English" and cannot adapt to the current employment needs and international environment. Teachers are annoyed. Students are helpless and students are helpless.

Student Issues. Many students do not pay enough attention to English learning, or lack of interest. They have formed a very passive situation in learning, and they can't even cope with the creativity of teachers. Many students are reluctant to participate in discussions in the classroom. Even simple questions and topics are not worthy or too lazy to think about. They feel lucky that if they are called by the teacher, they will either remain silent or use "sorry" or "I Don't know how to cope. Of course, students may indeed have language difficulties, but this is directly related to the passive learning habits that students have developed over a long period of time. The students' non-cooperation has also, to a certain extent, hit the teachers' enthusiasm for innovation and created a vicious circle.

Problems with the Current Examination System. The unilateral pursuit of test scores and pass rates in English teaching and examination seriously violates the objective laws of education and affects the quality of teaching. It is not conducive to mobilizing the enthusiasm, initiative, and creativity of students. Cultivating students' sense of innovation consciousness, innovative spirit, and innovative ability are even more empty words. In recent years, in order to improve the scientificity and objectivity of the tests, various standardized tests have come to the fore, such as the CET-4,CET-6 test. This type of test-oriented teaching is also often taught in large classes. As a result, students will only be memorized and eager for instant success. Many students receive more education and the thinking is more unitary. The narrower the angle of view, the more limited the imagination. In the long run, it repressed the student's autonomy and creativity, and this guidance is not conducive to the cultivation of innovative talents.

\section{The Internet + Era Brings Transformational Opportunity and Challenge to College English Education}

An important aspect of current college English teaching reform is the integration of relevant modern Internet technologies with traditional English teaching. Through modern teaching methods to improve the effectiveness of English teaching, the reform of English teaching mode. The "Internet $+"$ era has its unique advantages. It has: Universality - The Internet can be used to operate on a global scale and in all areas. Mobility - People can use their tablets, laptops, and other devices without restrictions of geographic location and time. Computers, mobile phones and other mobile devices to operate on the Internet. The rapid development and unique advantages of mobile Internet technology have changed the learning habits of English learners and the ways to acquire knowledge. At the same time, they have also changed the English teaching model, students' learning attitudes, and students' methods of learning English.

The Internet + Times Challenge the Traditional Classroom Teaching Methods and Teaching Contents of College English Education. All along, the model of college English classes has been teacher-centered and based on teaching materials. The traditional classroom teaching model considers students as "containers", that is, the recipient of passive knowledge, while constructivist learning theory believes that the best way of imparting knowledge is not through teacher's instruction but students' specific learning situations through the help of teachers and classmates, etc., the use of the information found, and a meaningful construction method. The development of Internet technology has brought novel teaching content and advanced teaching methods to college English education. Students can access the rich and varied language materials and online courses on the Internet anytime, anywhere. In the English class of the Internet age, the roles of teachers and students have changed.

The Construction of College English Innovative Teaching Mode under the Guidance of Internet + Education Theory. College English teaching requires all aspects of students' practical ability in English to be cultivated from the aspects of students' listening level, oral language level, reading article level, English writing level, and translation level. To break through the traditional 
English teaching model with poor efficiency at this stage, it is necessary to introduce the relevant content of Internet technology into English teaching. At the present stage, the flipping classroom teaching mode, micro-curriculum, and motto explored by the English education community are beneficial attempts in the field of Internet and education. Teachers can change the state of being completely separated from the classroom under the traditional class. Before the class, students can arrange learning tasks related to the learning content. Students are encouraged to search for relevant information through various mobile communication devices during their spare time and search as much as possible video and audio data.

\section{Relying on "Internet + " to Construct a Mode of Cultivating Talents for College English Innovation and Entrepreneurship}

In the context of "Internet + ", the college English teaching model makes use of the rich learning resources provided by the Internet platform to enable students to understand the market needs, thereby prompting students to actively participate in all aspects of teaching, from passive learning to active inquiry, and to strengthen practical training in the teaching process. It provides students with a broad space for development and improve their innovative ability. In order to change the traditional classroom mode in which teachers teach and students passively accept knowledge, British education should implement a teaching model based on knowledge foundation, project activity and actual training. In the process of classroom teaching, students should lay a solid foundation, improve their ability to listen, speak, read, write, and translate, and cultivate students' creativity and critical thinking. In the teaching process, we must make full use of the big data provided by Internet resources and platforms to bring students to practice under actual context.

Internet + Classroom Teaching Improves Teaching Effect. Internet + classroom teaching can create a new three-dimensional teaching platform. The combination of Internet technology and traditional teaching increases the amount of information in classroom teaching. It is rich in content, graphic and textual, vivid, and advancing with the times. The form of teaching is also more flexible. In addition to classroom lectures, teachers can also take the form of micro-classes, group discussions, student presentations, and concentration and answering questions. During the teaching process, students' participation, teaching content is interesting and vivid, and new content is achieved. The organic combination of new systems, new methods, and new methods. Classroom teaching makes effective use of Internet technology, and uses multimedia, micro-teaching, WeChat groups, and public numbers to expand the amount of teaching information, and enhances the interactivity and ubiquity of learning. Students can use the Internet resources to conduct independent learning and successfully complete preparatory studies, reviewing, answering questions, and developing exercises. Internet + classroom teaching provides students with a good learning environment, overcomes the shortcomings of traditional teaching models, stimulates students' interest and improves their English proficiency.

Internet + MOOC Teaching, Training students' Ability to Acquire Knowledge. The MOOC teaching should be mainly based on English knowledge and quality education. It adopts a diversified teaching mode and teaching methods, and relies on a three-dimensional network teaching system to comprehensively improve students' autonomous learning ability. Use moxie platform to achieve student self-learning, group discussion learning, large class inquiry learning, emphasizing resource sharing. The teaching mode of classroom teaching + MOOC teaching + practical teaching is enabled. The key to this model is to help students make full use of various high-quality educational resources, increase their knowledge, broaden their horizons, and think independently, and guide students to experience social life. Comprehend and solve practical problems in life.

Internet + teaching Management, Focusing on the Learning Process. College students' enthusiasm for learning is not high, and some students may even feel negatively tired of learning. To this end, we must strengthen the online, offline and combined supervision model. Teachers use the data provided by the Internet platform to monitor student learning. In the student learning process, the teacher checks the student's learning status on a weekly basis, reminds the student to 
complete the learning task in time, resolves problems encountered by the student in a timely manner through a communication platform, and organizes students to conduct online discussions and brainstorming. According to the student's learning situation and homework situation, the teacher concentrates on explaining key and difficult issues. This type of on-line supervision and teaching model increases the immediate interaction between teachers and students, improves learning efficiency, and stimulates students to think independently. Teachers can also improve teaching in a timely manner based on information feedback from students.

Internet + Project-driven, Intensified Practical Training. In the process of college English teaching, it is necessary to use Internet resources to find a program suitable for college students to learn English, so that students can "do by learning, learn by doing" and improve students' ability to apply, practice, and innovate. Encourage and instruct students to participate actively in college students' entrepreneurial projects, social practice projects, and teaching reform projects. In the implementation of the project, it is necessary to focus on the input of knowledge but also to train students' practical abilities, inspire students' sense of innovation, and achieve the goal of personnel training. In the project implementation process, a dual-track system of "introducing and going out" should be adopted, and experts and scholars with rich working experience and knowledge are to be recruited into the college English class to guide students to complete the project, and students should be encouraged to leave the campus and use "Internet+". "Looking for quality projects that allow students to really participate in the project, so as to enhance the academic level and practical ability of students, and lay a solid foundation for future career development.

\section{Summary}

In the context of the era of big data in which the Internet is integrated into all aspects of life, English education has adapted to the trends and trends of the development of the university's innovative and entrepreneurial ability. It has provided pressure on solving social and government employment, and helped students achieve their own personal values and social values an effective way. In the process of college English teaching, we must seamlessly connect with the real world and virtual learning platform, make full use of the resources, technologies, and platforms provided by the Internet to help students master extensive knowledge, cultivate students' sound personality, and establish teamwork awareness. At the same time, students' initiative should be brought into play, teachers' leading role should be strengthened, and the Internet should be used to cultivate students' ability to innovate and innovate.

\section{Preferences}

[1] WU Xiaojing, School of Economics. Linkage Mechanism of Cultivating Innovative Entrepreneurial Talents of Local Engineering Colleges[J]. Journal of Changsha University, 2015.

[2] WU Xiaojing, School of Economics. Linkage Mechanism of Cultivating Innovative Entrepreneurial Talents of Local Engineering Colleges[J]. Journal of Changsha University, 2015.

[3] Kuang D, Chen Y, Xurong Y U. College Students' Innovative Entrepreneurial Talents Training Mode Study[J]. China Educational Technology \& Equipment, 2014.

[4] Xiao Y, Jin X, Wang X. The Advantages and Effective Approaches in the Education and Training of Innovative and Entrepreneurial Talents of Colleges' Libraries[J]. Vocational Technology, 2015.

[5] Zhou H Y, Cheng W B, Pan L, et al. Research on the Mode of Cultivating Talents of Innovation and Entrepreneurship in Local Colleges and Universities[J]. Electronic Technology, 2017.

[6] Chen Y, Wang Y Y, Liu H G, et al. Actively Explore Path to Social Practice \& Cultivate Innovative and Entrepreneurial Talent of University[J]. Value Engineering, 2013.

[7] Xian-Chun S U, Yan G P. Research and practice of innovative and entrepreneurial talents training model in engineering colleges[J]. Journal of Jilin Institute of Chemical Technology, 
2017.

[8] Shao L, Pan W. Research on Cultivation of Innovative Entrepreneurial Talents in Industrial-academic-research Cooperative Mode[J]. Journal of Jiyuan Vocational \& Technical College, 2017.

[9] Le Q I, Liu L. Exploration and Research on Innovation and Entrepreneurship Talents in Engineering Colleges[J]. Education Teaching Forum, 2016.

[10] Shen P. Promoting the Cultivation of Innovation and Entrepreneurial Talent in Higher Vocational Colleges with the Maker Education[C]// International Conference on Innovations in Economic Management and Social Science. 2017.

[11] Diao M, Gao X, University H. Research on Cultivating College Innovative and Entrepreneurial Talents in the Context of "Longjiang Silk Road Economic Belt" [J]. Journal of Heihe University, 2017.

[12] Liu K. Exploration on Training Mode of Innovative and Entrepreneurial Talents of Applied Chemistry Specialty in Local Colleges[J]. Guangzhou Chemical Industry, 2017.

[13] Wan J. Higher vocational college computer professional innovative entrepreneurial talent training[J]. Journal of Jiamusi Vocational Institute, 2015.

[14] Dou X H, Business S O, University J. A Study on Colleges and Universities' Innovation and Entrepreneurship Talents Cultivation Approach[J]. Education Teaching Forum, 2017. 